\title{
KONTRIBUSI MODEL PEMBELAJARAN KOOPERATIF TIPE STAD DALAM PEMBELAJARAN IPS TERHADAP PENGUASAAN KONSEP SISWA
}

\author{
M. Taufik \\ Surel:putramllk@yahoo.com.
}

\begin{abstract}
The aims of this study is to know how about contribution of STAD type cooperative learning model in IPS Madrasah Ibtidaiyah learning to mastery of student concept. This research uses quasi experimen method, which is done in two class groups, namely: control group and experiment group in fourth grade students of Madrasah Ibtidaiayah Negeri Korong Gadang Kota Padang. Data collection techniques in this study through, test, observation and interviews and documentation. IPS learning with STAD type Cooperative Learning model contributes positively to the improvement of students' concept of mastery. So based on this research STAD model Cooperative Learning model can be the alternative for teachers in Madrasah Ibtidaiayah or in Elementary School who want the realization of IPS learning objectives as expected. Obtain the average gain and $N$ gain of 1.06 and 0.01 in the control class and 2.38 and 0.02 in the experimental class.
\end{abstract}

Keywords: Leaning Model STAD, IPS, Mastery of Student Consept.

\begin{abstract}
ABSTRAK
Tujuan dari penelitian ini adalah untuk mengetahui seberapa besar kontribusi model pembelajaran kooperatif tipe STAD dalam pembelajaran IPS Madrasah Ibtidaiyah terhadap penguasaan konsep siswa. Penelitian ini menggunakan metode quasi ekperimen, yang dilakukan pada dua kelompok kelas yaitu: kelompok kontrol dan kelompok ekperimen pada siswa kelas IV Madrasah Ibtidiayah Negeri Korong Gadang Kota Padang. Teknik pengumpulan data yang digunakan dalam penelitian ini melalui, test, observasi dan wawancara dan dokumentasi. Pembelajaran IPS dengan model Cooperative Learning tipe STAD berkontribusi positif terhadap peningkatan penguasaan konsep siswa. Hal ini dapat dibuktikan dengan membandingkan nilai gain dan $\mathrm{N}$-gain antara kelas kontrol dan ekperimen. Diperoleh rata-rata gain dan N-gain 1,06 dan 0,01 pada kelas kontrol dan 2,38 dan 0,02 pada kelas ekperimen.
\end{abstract}

Kata Kunci: Model Pembelajaran STAD, IPS, Penguasaan Konsep.

\section{PENDAHULUAN}

Pendidikan merupakan upaya yang dilakukan secara sadar yang diarahkan untuk mencapai perbaikan di segala aspek kehidupan. Upaya perbaikan yang diupayakan itu hendaknya juga dilakukan secara menyeluruh dan mencakup pengembangan aspek moral, akhlak, budi, pekerti, perilaku, pengetahuan, kesehatan, keterampilan dan seni. Dalam Undang-Undang No. 20 Tahun 2003 tentang sistem pendidikan nasional dinyatakan secara tegas bahwa: Pendidikan Nasional befungsi untuk mengembangkan kemampuan dan membentuk watak serta peradaban bangsa yang 


\begin{abstract}
bermartabat dalam rangka mencerdaskan kehidupan bangsa, bertujuan untuk berkembangnya potensi peserta didik agar menjadi manusia yang beriman dan bertaqwa kepada Tuhan Yang Maha Esa, berakhlak mulia, sehat, berilmu, cakap, kreatif, mandiri, dan menjadi warganegara yang demokratis serta bertanggung jawab.
\end{abstract}

Sekolah sebagai lembaga pendidikan formal mempunyai tanggung jawab yang besar untuk mewujudkan cita-cita bangsa ini sebagaimana yang diamanahkan dalam undang-undang sistem pendidikan nasional tersebut. Ini semua tidak hanya menjadi tugas dan tanggung jawab satu bidang keilmuan saja tapi ini merupakan tugas dan tanggung jawab multidisipliner dari berbagai bidang keilmuan.

Sekolah dasar sebagai lembaga pendidikan formal merupakan ujung tombak dari keberlansungan pendidikan selanjutnya, sebagaimana yang dinyatakan dalam Peraturan Pemerintah Nomor 19 tahun 2005 bab V Pasal 26 ayat 1 (PP No 19 2005) dinyatakan bahwa: Tujuan pendidikan dasar adalah untuk meletakkan dasardasar kecerdasan, pengetahuan, akhlak mulia, serta keterampilan untuk hidup mandiri dan mengikuti pendidikan lebih lanjut. tujuan pendidikan dasar ini harus tercermin dalam kurikulum pendidikan pendidikan dasar.

Pendidikan Ilmu Pengetahuan Sosial merupakan salah satu dari mata pelajaran yang diberikan disekolah dasar yang materi ajarnya banyak berhubungan dengan manusia dan berbagai macam bentuk aktivitasnya. Dalam kurikulum 2004 Sekolah Dasar, Departemen Nasional dinyatakan bahwa, pengertian Ilmu Pengetahuan Sosial disekolah Dasar merupakan bahan kajian secara terintegrasi yang diadaptasi, disederhanakan, diseleksi, dan dimodifikasi dari konsep-konsep dan keterampilan sejarah, geografi, sosiologi, antropologi, dan ekonomi. Fungsi mata pelajaran ilmu pengetahuan sosial di Sekolah adalah mengembangkan pengetahuan, nilai dan sikap, serta keterampilan sosial siswa untuk dapat menelaah kehidupan sosial yang dihadapi sehari-hari serta menumbuhkan rasa bangga dan cinta terhadap perkembangan masyarakat Indonesia sejak masa lalu hingga masa kini. Hal ini juga sejalan dengan pendapat Banks (1990) bahwa:

"The social studies is that part of the elementary and high school curriculum which has the primary responsibility for helping students to develop the knowledge, skill, attiude, and values needed to participate in the civic life of their local communities, the nation and he world,......the social studies is the only area that has the development of civic competencien and skill as its primary goal".

Berdasarkan pengertian ini, Ilmu Pengetahuan Sosial (Social Studies) merupakan bagian dari kurikulum sekolah dasar dan menengah yang mempunyai tanggung 
jawab pokok membantu siswa untuk mengembangkan pengetahuan, keterampilan, sikap dan nilai yang diperlukan dalam hidup bernegara dalam lingkungan masyarakatnya, namun tujuan mengembangkan kompetensi dan keterampilan hidup bernegara menjadi tujuan utama dari ilmu sosial itu. Numan Somantri (2001) menyatakan juga bahwa: a) Pendidikan Ilmu Pengetahuan Sosial ditingkat sekolah dasar dapat dijadikan wahana tumbuhnya nilainilai kewarganegaraan, moral ideologi negara dan nilai agama, b) pendidikan IPS menekankan pada isi dan metode berpikir ilmuwan sosial, c) Pendidikan ilmu pengetahuan sosial yang menekankan pada reflective inquiry, dan d) pendidikan IPS yang mengambil kebaikan dari butir a,b,c diatas.

Tujuan dari pembelajaran IPS terutama di sekolah dalam belum terwujud secara maksimal, hal ini bisa dilihat masih rendahnya prestasi akademik siswa. Belum terwujudnya nilai-nilai tujuan pembelajaran ilmu pengetahuan sosial sebagaimana yang telah disebutkan tidak terlepas dari berbagai faktor yang mempengaruhinya. Salah satu faktor yang sangat penting adalah dalam hal penggunaan metode pembelajaran yang efektif untuk mewujudkan tujuan-tujuan dari setiap mata pelajaran yang ada, terutama dalam mata pelajaran IPS sekolah dasar.

Guru sebagai motor dalam penyelenggaraan proses pembelajaran sangat dituntut untuk memiliki wawasan tentang penggunaan model yang efektif dalam pembelajaran, namun juga dimaklumi tidak semua guru mempunyai pemahaman tentang itu

Solihatin, et. al (2007) menyatakan bahwa kondisi pembelajaran IPS saat ini masih ditemukan kelemahan-kelemahan dilapangan antara lain 1) model pembelajaran konvensional/ceramah, 2) siswa hanya dijadikan objek pembelajaran. Pembelajaran yang berlansung cenderung tidak melibatkan pengembangan pengetahuan sosial siswa, karena guru selalu mendominasi pembelajaran (teacher centered) akibatnya proses pembelajaran sangat terbatas, sehingga kegiatan pembelajaran hanya diarahkan pada mengetahui (learning to know), kearah pengembangan kognitif dan mengabaikan pengembanagan afektif serta psikomotor, 3) Pelajaran IPS bersifat hafalan semata sehingga siswa kurang bergairah dalam belajar,4) dalam proses pembelajaran pola interaksi searah, hanya dari guru kesiswa. Sejalan dengan itu Suwarna Al Mukhtar (2001) menyatakan bahwa, siswa dalam ilmu pengetahuan sosial masih belum optimal diperankan sebagai subjek pembelajar, siswa belum belum dijadikan fokus sentral dalam kontruksi pemikiran peningkatan mutu pendidikan. Perlunya siswa untuk diperankan sebagai pembelajar, menuntut untuk diciptakannya lingkungan belajar yang memungkinkan proses belajar itu terjadi. 
Berdasarkan diatas nampak bahwa pada satu sisi betapa pentingnya peranan pendidikan IPS dalam mengembangkan pengetahuan, nilai, sikap, dan keterampilan sosial agar para siswa menjadi warga masyarkat, bangsa dan negara indonesia yang baik namun dipihak lain masih banyak ditemukan dalam kelemahan dalam pembelajaran IPS terutama dalam hal metode pembelajaran. Maka untuk mengatasi problem ini sangat diperlukan adanya perubahan, terutama perubahan dalam hal model pembelajaran, sehingga dengan adanya model itu diharapkan akan terjadi perubahan yang diinginkan terhadap siswa tidak hanya dari segi kognitif tapi tapi juga afektif dan psikomotornya.

Dalam konteks itu, maka karakter dan model pembelajaran terutama Ilmu Pengetahuan Sosial perlu merujuk pada prinsip-prinsip yang di rumuskan National Council For the Social Studies (NCSS) dimana sangat menekankan pada makna kekuatan pendidikan IPS sebagai berikut: The essential characteristics of powerful social studies consist of the five principles are as follows: 1) Social studies teaching and learning are powerful when they are meaning ful, 2) Social studies teaching and learning are powerful when they are integrative, 3) Social studies teaching and learning are powerful when they are values based, 4) Social studies teaching and learning are powerful when they are challenging dan 5) Social studies teaching and learning are powerful when the learning is active. (NCSS, Myers, 2000 dalam Nursid, 2006).

Maksud dari rumusan tersebut adalah bahwa dalam proses pembelajaran pengetahuan sosial yang harus selalu memperhatikan kebermaknaannya, pada proses pembelajaran perlu terintergrasi baik domain maupun contents, berlandasan nilai, menantang, dan berkembang dalam suasana aktif.

Untuk mengembangkan pembelajaran ilmu pengetahuan sosial sesuai dengan tuntunan kurikulum perlu penyeleksian terhadap pendekatan yang sesuai dengan hakikat pengetahuan sosial yang berlandasan pada lima prinsip tersebut.

Diantara model pembelajaran diatas, model pembelajaran cooperative learning dipandang cocok untuk bisa meningkatkan pengembangan kognitif, afektif serta psikomotor siswa. Hal ini bisa kita lihat tujuan dari penggunaan model pembelajaran kooperatif itu sendiri. Ibrahim et, al (2007) menyatakan, Cooperative Learning dikembangkan untuk mencapai setidak-tidaknya tiga tujuan pembelajaran penting, yaitu: a) Hasil belajar akademik, b) Penerimaan terhadap Individu, dan c) Pengembangan Keterampilan Sosial (Social Skill)

Siswa yang dibelajarkan dengan cooperative learning cenderung menunjukkan peningkatan prestasi akademik, keterampilan berpikir yang lebih baik, lebih menguasai materi pembelajaran, memiliki motivasi diri lebih besar 
untuk belajar dan berprestasi, memiliki hubungan yang lebih baik dengan kelompok dan menghargai dirinya sendiri dengan lebih baik (Felder \& Brent, 1994).

Model pembelajaran kooperatif ini banyak yang bisa terapkan dalam pembelajaran IPS di sekolah dasar ataupun Madrasah ibtidaiyah, seperti model TGT (Team -Game-Turnamen), STAD (Student Teams-Achievement Division), TAI (Team-Assisted- Individuazation), Ivestigasi kelompok (Group Investigation) dan masih banyak model lainnya. Namun penulis melihat bahwa model yang cocok dibanding model lain dalam meningkatkan penguasaan konsep siswa adalah model STAD.

Ada beberapa alasan menurut penulis kenapa model ini cocok dalam meningkatkan penguasaan konsep siswa dalam pembelaajaran IPS serta keterampilan sosial siswa yaitu: a) Setiap komponen dari model pembelajaran kooperatif secara umum terkandung dalam model pembelajaran STAD, b) Ada nilai lebih dalam model pembelajaran STAD yaitu adanya pemberian poin dari tiap individu terhadap kelompoknya.

\section{METODE PENELITIAN}

Penelitian ini merupakan penelitian dengan metode eksperimen semu (quasi eksperimen). Bentuk desain penelitian ini adalah nonequivalent groups pre-test-posttest design. Dimana desain ini terdapat dua kelompok, yaitu kelompok eksperimen dan kelompok control. Subyek penelitian adalah siswa kelas IV B semester II Madrasah Ibtidaiyah Negeri Korong Gadang kota Padang sebagai kelompok eksperimen dengan jumlah siswa 35 orang, sedangkan sebagai kelompok kontrol adalah siswa kelas IV A MIN Korong Gadang dengan jumlah siswa 32 orang.

Instrumen yang digunakan dalam penelitian ini dalam bentuk tes. Tes ini digunakan untuk mengukur hasil atau penguasaan siswa terhadap materi ajar berupa peningkatan pemahaman kognitif siswa, yang dilakukan dengan pretes dan postes sebelum dan setelah metode Cooperative Learning tipe STAD (Student Team Achievment Divisions) diterapkan dengan indikator kemampuan pengetahuan, pemahaman, dan penerapan siswa dalam belajar.

Pengolahan data secara garis besar dilakukan dengan menggunakan bantuan pendekatan secara hirarki statistik. Data primer dan hasil tes siswa sebelum dan sesudah pembelajaran dengan pendekatan Cooperative Learning Tipe STAD (Student Team Achievement Division) dianalisa dengan cara membandingkan skor pretes dan postes. Peningkatan yang terjadi sebelum dan sesudah pembelajaran dihitung dengan rumus gain faktor (N-Gain) dengan rumus:

$$
g=\frac{S_{\text {post }}-S_{\text {pre }}}{S_{\text {maks }}-S_{\text {pre }}}
$$

(Meltzer, 2002) 
M. Taufik: Kontribusi Model Pembelajaran...

Keterangan:

$$
\begin{aligned}
& S_{\text {post }}: \text { Skor postes } \\
& S_{\text {pre }}: \text { Skor pretes } \\
& S_{\text {maks }}: \text { Skor maks ideal }
\end{aligned}
$$

Kriteria tingkatan Gain adalah

Tabel 1. Kategori Tingkat Gain

\begin{tabular}{c|c}
\hline Batasan & Kategori \\
\hline $\mathrm{g}>0.7$ & Tinggi \\
\hline $0.3 \leq \mathrm{g} \leq 0.7$ & Sedang \\
\hline $\mathrm{g}<0.3$ & Rendah \\
\hline
\end{tabular}

\section{HASIL PENELITIAN DAN} PEMBAHASAN

Penguasaan Konsep Siswa Dalam Pembelajaran IPS dengan Model Pembelajaran Kooperatif tipe STAD.

Bagian ini melihat bagaimana pengujian terhadap penguasaan konsep siswa terhadap materi ajar berdasarkan kemampuan menjawab tes dalam bentuk pilihan ganda. Serta melihat perbedaan skor tes yang diperoleh pada siswa kelas kontrol dengan kelas ekperimen.

\section{a. Kemampuan Awal Pengusaan Konsep Siswa \\ Kemampuan awal siswa} diperoleh berdasarkan tes penguasaan konsep dalam bentuk pilihan ganda sebelum penerapan pembelajaran. Data yang diperoleh dari responden, dari kelas kontrol diperoleh skor ratarata pretes sebesar 12, 81 dengan varians yaitu 3,83. Sedangkan pada data kelas ekperimen diperoleh skor rata-rata yaitu 12,82 dengan varians yaitu 5,73.

Untuk melihat perbedaan skor awal (pretes) kelas kontrol dengan ekperimen maka dilakukan dengan dua uji statistik yaitu statistik parametrik (Uji-t) dan ststistik nonparametrik (Uji Wilcoxon). Uji-t bisa dilakukan jika data kelas kontrol dan ekperimen berdistribusi normal dan homogen, sebaliknya jika data tidak normal dan tidak homogen maka uji beda bisa dilakukan dengan Uji Wilcoxon.

Uji Normalitas data penguasaan konsep dilakukan dengan Analisi one sample K-S (KolmogorovSmirnov) pada program SPSS versi 17. Pengujian ini dapat dilakukan dengan membandingkan probalitas (sig) dengan nilai alpha $(\alpha)$, kriteria penilaian adalah apabila probalitas (sig) > alpha $(\alpha)$, maka hasil tes dikatakan berdistribusi normal. Hipotesis pengujian normalitas adalah dengan menggunakan kolmogorovSmirnov adalah sebagai berikut:

H0: angka signifikan (sig) > 0,05 maka data berdistribusi normal $\mathrm{H1}$ : angka signifikan (Sig) $<0,05$ maka data tidak berdistribusi normal.

Berdasarkan data dilapangan setelah dilakukan uji normalitas dengan menggunakan KolmogorvSmirnov diperoleh hasilnya pada table dibawah ini: 
Tabel 2. Hasil Uji Normalitas Data Awal Tes Penguasaan Konsep

\begin{tabular}{c|l|c|c|c}
\hline No & \multicolumn{1}{|c|}{ Data } & Asy.Sig & $\boldsymbol{\alpha}$ & Ket \\
\hline 1 & $\begin{array}{l}\text { Pretest } \\
\text { Kelas } \\
\text { Kontrol }\end{array}$ & 0.644 & 0,05 & Normal \\
\hline 2 & $\begin{array}{l}\text { Pretest } \\
\text { Kelas } \\
\text { Eksperimen }\end{array}$ & 0.177 & 0,05 & Normal \\
\hline
\end{tabular}

Berdasarkan data dari tabel 2 di atas dapat kita pahami, bahwa data pretest kelas kontrol diperoleh angka signifikan (Sig) lebih besar dari nilai alpha $(\alpha)$ atau $0.644>0,05$, maka dapat dikatakan data itu berdistribusi normal. Hasil uji normalitas data pretest kelas eksperimen diperoleh angka signifikan (Sig) lebih besar dari nilai $\alpha$ lpha $(\alpha)$ atau $0.177>0,05$. Artinya data pretest kelas ekperimen berdistribusi normal.

Dari hasil uji normalitas dengan menggunakan KolmogorovSmirnov terhadap data pretest kelas kontrol dan pretes kelas ekperimen dapat disimpulkan bahwa kedua data berdistribusi normal.
Uji homogenitas pada prinsipnya adalah ingin menguji apakah sebuah grup (data ketegori) mempunyai varians yang sama di antara anggota grup tersebut (Santoso, 2003). Uji homogenitas dapat digunakan dengan two related Samples Test. Untuk menentukan tingkat homogenitas data dapat dilakukan dengan membandingkan angka signifikan (Sig) lebih besar dari alpha (0,05), maka Ho ditolak, sebaliknya jika angka signifikan (Sig) lebih kecil dari $\alpha(0,05)$, maka Ho diterima. Berdasarkan hasil uji homogenitas data penguasaan konsep dapat dilihat dalam tabel 3 dibawah ini:

Tabel 3. Hasil Uji Homogenitas Data Awal Penguasaan Konsep Siswa

\begin{tabular}{c|c|c|c}
\hline \multicolumn{1}{c|}{ Data } & Asymp. Sig & $\boldsymbol{\alpha}$ & Ket. \\
\hline $\begin{array}{l}\text { Pretes Kelas Kontrol - } \\
\text { Pretes Kelas Eksperimen }\end{array}$ & 0,815 & 0,05 & Homogen \\
\hline
\end{tabular}

Berdasarkan tabel 3 di atas, pada kelas pretest kelas kontrol dan pretest kelas ekperimen didapat angka signifikan (Sig) lebih besar dari alpha $(\alpha)$ atau $0,815>0,05$. Ini berarti data pretes kelas kontrol dan pretes kelas ekperimen homogen dan Ho ditolak.

Dari hasil uji normalitas dan homogenitas data pretest kelas kontrol dan pretes kelas ekperimen maka pengolahan data memenuhi 
syarat untuk uji komparatif dengan menggunakan data statistik parametrik (uji-t).

Uji beda kelas kontrol dan kelas ekperimen dilakukan dengan statistic parametric (Uji-t) dengan kaidah pengujian hipotesis sebagai berikut:

H0 : Tidak ada perbedaan rata-rata skor pada kedua kelas
H1 : terdapat perbedaan rata-rata skor pada kedua kelas

adalah:

Dengan kriteria pengujian

Jika harga $t_{\text {hitung }}>$, ttabel, berarti hipotesis H0 diterima, dan

Jika harga $t_{\text {hitung }}<$, berarti hipotesis Ho ditolak

Hasil uji-t data penguasaan konsep dapat dilihat dalam tabel dibawah ini:

Tabel 4. Hasil Uji-t Terhadap Data Awal Penguasaan Konsep

\begin{tabular}{l|l|l|l|l|l}
\hline \multicolumn{1}{c|}{ Data } & \multicolumn{1}{c|}{$\mathbf{t}_{\text {hitung }}$} & Df & $\mathbf{t}_{\text {tabel }}$ & Sig & Keterangan \\
\hline & & & & & \\
$\begin{array}{l}\text { Pretes kelas Kontrol- } \\
\begin{array}{l}\text { Pretest kelas } \\
\text { eksperimen }\end{array}\end{array}$ & $-0,230$ & 33 & 2.042 & 2.042 & $\begin{array}{l}\text { Tidak ada } \\
\text { perbedaan } \\
\text { yang } \\
\text { signifikan }\end{array}$ \\
\hline
\end{tabular}

Pada tabel 4 di atas, pengujian pertama dilakukan untuk mengetahui perbedaan rata-rata nilai pretest kelas kontrol dan kelas ekperimen. Hasil perhitungan uji-t menunjukkan nilai pretest kelas kontrol dan kelas ekperimen dengan nilai thitung sebesar -0.538 dan nilai tabel untuk pada taraf signifikan 0,05 dan df $=33$ diperoleh nilai ttabel 2.042. karena nilai $t_{\text {hitung }}$ negatif maka tabel mengikut yaitu -2.021. Ini berarti nilai $t_{\text {hitung }}$ lebih kecil dari nilai tabel atau $-0,230<$ -2.024 berarti Ho ditolak. Dengan melihat taraf signifikan diperoleh angka signifikan lebih besar dari nilai alpha $(\alpha)$ atau $2.024>0,05$, ini juga berarti tidak ada perbedaan yang signifikan skor rata-rata pretest kelas kontrol dengan kelas ekperimen. Maka berdasarkan uji-t ini dapat disimpulkan bahwa data pada pretes kelas ekperimen dan kelas kontrol tidak terdapat perbedaan yang signifikan.

b. Kemampuan Akhir Penguasaan Konsep Siswa

Kemampuan penguasaan konsep siswa merupakan skor yang diperoleh siswa setelah adannya pembelajaran baik pada kela kontrol maupun pada kelas ekperimen. pada data awal kelas kontrol diperoleh skor rata-rata sebesar 13,88 sementara pada kelas ekperimen diperoleh ratarata skor sebesar 16,26.

Untuk melihat perbedaan skor awal (pretes) kelas kontrol dengan ekperimen maka dilakukan dengan dua uji statistik yaitu statistik 
parametri (Uji-t) dan ststistik nonparametrik (Uji Wilcoxon). Uji-t bisa dilakukan jika data kelas kontrol dan ekperimen berdistribusi normal dan homogen, sebaliknya jika data tidak normal dan tidak homogen maka uji beda bisa dilakukan dengan Uji Wilcoxon.

Uji Normalitas data penguasaan konsep dilakukan dengan Analisis one sample $K-S$ (Kolmogorov-Smirnov ) pada program SPSS versi 17. Pengujian ini dapat dilakukan dengan membandingkan probalitas (sig) dengan nilai alpha $(\alpha)$, kriteria penilaian adalah apabila probalitas (sig) > alpha $(\alpha)$, maka hasil tes dikatakan berdistribusi normal. Hipotesis pengujian normalitas adalah dengan menggunakan kolmogorov-Smirnov adalah sebagai beriku:

H0: angka signifikan (sig) > 0,05 maka data berdistribusi normal

H1: angka signifikan (Sig) $<0,05$ maka data tidak berdistribusi normal

Berdasarkan data dilapangan setelah dilakukan uji normalitas dengan menggunakan KolmogorvSmirnov diperoleh hasilnya pada tabel dibawah ini:

Tabel 5. Hasil Uji Normalitas Data Akhir Tes Penguasaan Konsep

\begin{tabular}{c|lr|c|c|c}
\hline No & \multicolumn{2}{|c|}{ Data } & Asym.Sig & A & Keterangan \\
\hline 1 & $\begin{array}{l}\text { Postest Kelas } \\
\text { Kontrol }\end{array}$ & 0.417 & 0,05 & Normal \\
\hline 2 & $\begin{array}{l}\text { Postes Kelas } \\
\text { Eksperimen }\end{array}$ & 0.142 & 0,05 & Normal \\
\hline
\end{tabular}

Berdasarkan data dari Tabel di atas pada uji normalitas postest kelas kontrol diperoleh angka signifikan (Sig) lebih besar dari nilai alpha $(\alpha)$ atau $0.417>0.05$. dengan demikian data postest kelas kontrol berdistribusi normal. Sedangkan untuk kelas postest ekperimen juga didapat angka signifikan (sig) lebih besar dari nilai $\alpha$ lpha $(\alpha)$ atau $0.177>0,05$. Dari hasil uji normalitas dengan menggunakan Kolmogorov-Smirnov terhadap pada data dan postest kelas kontrol dan kelas ekperimen dapat disimpulkan data beridistribusi normal. Oleh karena itu maka analisis uji beda dengan menggunakan statistik parametrik dapat dilanjutkan.

Uji homogenitas dapat digunakan dengan Two Related Samples Test. Untuk menentukan tingkat homogenitas data dapat dilakukan dengan membandingkan angka signifikan (Sig) lebih besar dari 
M. Taufik: Kontribusi Model Pembelajaran...

alpha (0,05), maka Ho ditolak,

Berdasarkan hasil uji sebaliknya jika angka signifikan (Sig) homogenitas data penguasaan konsep lebih kecil dari $\alpha(0,05)$, maka Ho dapat dilihat dalam tabel dibawah ini: diterima.

Tabel 6. Hasil Uji Homogenitas Alat Ukur Penguasaan Konsep Siswa

\begin{tabular}{l|c|c|c}
\hline \multicolumn{1}{c|}{ Data } & $\begin{array}{c}\text { Asymp. } \\
\text { Sig }\end{array}$ & A & Keterangan \\
\hline $\begin{array}{l}\text { Postest Kelas } \\
\begin{array}{l}\text { Kontrol- } \\
\text { Postest Kelas }\end{array}\end{array}$ & 0,001 & 0,05 & $\begin{array}{c}\text { Tidak } \\
\text { Homegen }\end{array}$ \\
Eksperimen & & & \\
\hline
\end{tabular}

Berdasarkan table 6 diatas, kaidah pengujian hipotesis sebagai skor postest kelas kontrol dan kelas ekperimen menunjukkan nilai berikut:

Asym,sig sebesar 0,001 lebih kecil dari nilai probabalitas $\alpha$ lpha $(\alpha)$ yaitu 0,05. Maka berdasarkan ini data tidak homogen.

Dari hasil uji normalitas dan homogenitas data potes kelas kontrol dan kelas maka pengolahan data memenuhi syarat untuk uji komparatif dengan menggunakan data statistik parametrik (uji-t).

Uji beda kelas kontrol dan kelas ekperimen dilakukan dengan H0 : Tidak ada perbedaan rata-rata skor pada kedua kelas

H1 : terdapat perbedaan rata-rata skor pada kedua kelas

Dengan kriteria pengujian adalah:

Jika harga $t_{\text {hitung }}>, t_{\text {tabel, }}$ berarti hipotesis H0 diterima, dan

Jika harga $t_{\text {hitung }}<$, berarti hipotesis Ho ditolak

Hasil uji-t data penguasaan konsep dapat dilihat dalam tabel dibawah ini:

Tabel 7. Hasil Uji-t Terhadap Data Akhir Penguasaan Konsep

\begin{tabular}{l|l|l|l|l|l}
\hline \multicolumn{1}{c|}{ Data } & thitung & Df & $\mathbf{t}_{\text {tabel }}$ & Sig & Keterangan \\
\hline $\begin{array}{l}\text { Postest Kelas Kontrol - } \\
\begin{array}{l}\text { Postest Kelas } \\
\text { Eksperimen }\end{array}\end{array}$ & $-4,268$ & 33 & 2.042 & 0,000 & $\begin{array}{l}\text { Terdapat perbedaan } \\
\text { yang signifikan }\end{array}$ \\
\hline
\end{tabular}

Pada tabel di atas pengujian pertama dilakukan untuk mengetahui perbedaan rata-rata nilai postest kelas kontrol dan kelas ekperimen. Hasil 
perhitungan uji-t pada data postest kelas kontrol dan postest kelas kontrol diperoleh $t_{\text {hitung }}$ sebesar $-4,268$ dan $t_{\text {tabel }}$ pada taraf signifikan 0,05 dan df $=33$ diperoleh $t_{\text {tabel }}$ sebesar 2.042 . data ini menunjukkan $t_{\text {hitung }}$ lebih kecil dari t tabel atau $-4,268<2.042$ berarti Ho ditolak. Dan pada taraf signifikan dapat dilihat bahwa nilai probabalitas sig lebih kecil dari nilai $\alpha$ lpha $(\alpha)$ atau $0,000<0,05$ dan ini berarti pada data ini terdapat perbedaan yang signifikan skor rata-rata postest kelas kontrol dengan postest kelas ekperimen.

Berdasarkan uraian tabel diatas dapat disimpulkan bahwa terdapat perbedaan yang signifikan data akhir penguasaan konsep siswa kelas kontrol dengan data akhir siswa kelas ekperimen.
c. Perbedaan Data Awal dan Akhir Penguasaan Konsep Siswa

Adapun langkah yang akan dilakukan setelah mengetahui kemampuan awal dan akhir penguasaan konsep siswa pada kelas kontrol dan kelas ekperimen adalah membandingkan kemampuan awal dan kemampuan akhir dari masingmasing kelas. Dengan kata lain membandingkan antara kemampuan awal penguasaan konsep kelas kontrol dengan kemampuan akhir penguasaan konsep kelas kontrol. Serta membandingkan kemampuan awal data penguasaan konsep siswa pada kelas ekperimen dengan kemampuan akhir data penguasaan konsep siswa pada kelas ekperimen.

Perbandingan hasil kemampuan awal (pretes) penguasaan konsep dengan kemampuan akhir (postes) penguasaan konsep. Berdasarkan uji-t dapat dilihat dalam tabel dibawah ini:

Tabel 8. Hasil Uji-t Pretes dan Postes Penguasaan Konsep

\begin{tabular}{l|c|c|c|c|c}
\hline \multicolumn{1}{c|}{ Data } & $\mathbf{t}_{\text {hitung }}$ & Df & $\mathbf{t}_{\text {tabel }}$ & Sig & Keterangan \\
\hline $\begin{array}{l}\text { Pretes Kelas } \\
\text { Kontrol - }\end{array}$ & $-2,953$ & 34 & 2.021 & 0.006 & $\begin{array}{c}\text { Terdapat perbedaan yang } \\
\text { sigifikan }\end{array}$ \\
$\begin{array}{l}\text { Postest Kelas } \\
\text { Kontrol }\end{array}$ & & & & & \\
\hline $\begin{array}{l}\text { Pretes kelas } \\
\text { Ekperimen- } \\
\text { Postest kelas } \\
\text { Ekperimen }\end{array}$ & $-9,660$ & 33 & 2.042 & 0,000 & $\begin{array}{c}\text { Terdapat perbedaan yang } \\
\text { signifikan }\end{array}$ \\
\hline
\end{tabular}

Hasil perihitungan uji-t pada tabel diatas, diketahui nilai skor pretest kelas kontrol dan postes kelas kontrol dengan $t_{\text {hitung }}$ sebesar $-02,953$ nilai $t_{\text {tabel }}$ untuk pada taraf siginifikan 0,05 dan $\mathrm{df}=34$ diperoleh nilai sebesar 2,021. Nilai $t_{\text {tabel }}$ mengikuti $t_{\text {hitung }}$ Karena nilai $t_{\text {hitung }}$ negatif maka $t_{\text {tabel menjadi negatif. Kriteria }}$ pengujian adalah jika $t_{\text {hitung }}<t_{\text {tabel }}$ maka Ho ditolak dan jika $t_{\text {hitung }}>t_{\text {tabel }}$ maka H0 diterima. Maka berdasarkan 
data skor rata -rata pretest dan postes kelas kontrol dapat dilihat $t_{\text {hitung }}$ lebih kecil dari tabel atau $-0,2,953<2,021$ berarti Ho ditolak. Dan untuk melihat tingkat siginifikannya dapat dilihat dengan kriteria jika probabalitas nilai sig > dari alpha ( 0,05) maka tidak signifikan dan jika nilai probabalitas sig < nilai alpha maka signifikan. Maka berdasarkan ini pada data pretest dan postes kelas kontrol diperoleh nilai probabalitas nilai Asym. Sig lebih kecil dari nilai alpha atau $0,006<0,05$. Ini berarti terdapat perbedaan yang signifikan skor ratarata pretest kelas kontrol dengan postes kelas kontrol.

Hasil perhitungan uji-t pada data pretest postest kelas ekperimen diperoleh data thitung sebesar -9.660 dan nilai ttabel pada taraf signifikan 0,05 dan $\mathrm{df}=33$ diperoleh $\mathrm{t}_{\text {tabel }}$ sebesar 2.042. data ini menujukkan thitung lebih kecil dari tabel atau $-9.660<2,042$, bererti Ho ditolak. Dan Pada taraf signifikansi dapat dilihat nilai probabalitas sig lebih kecil nilai alpha atau $0,000<0,05$. Berdasarkan data ini dapat disimpulkan terdapat perbedaan yang signifikan antara pretest kelas ekperimen dengan postest kelas ekperimen.

\section{d. Gain dan N-gain Penguasaan Konsep}

Pada data penguasaan konsep kelas kontrol diperoleh gain sebesar 1,06 dengan $\mathrm{N}$-gain sebesar 0,01 . Sementara pada kelas ekperimen data penguasaan konsep siswa diperoleh gain sebesar 3,44 dengan $\mathrm{N}$-gain sebesar 0,03. Dari perbandingan antara kelas kontrol dengan kelas ekperimen diperoleh gan dan $\mathrm{N}$-gain kelas ekperimen lebih besar dari gain dan $\mathrm{N}$-gain kelas kontrol, dengan Selisih 2,38 untuk gain dan 0,02 untuk $\mathrm{N}$-gain

Berdasarkan hasil pengujian statistik dengan menggunakan uji-t terhadap nilai rata-rata pretest kelas kontrol dan pretest kelas ekperimen menujukkan adanya perbedaan. Hal ini dibuktikan dengan membandingkan nilai thitung kecil dari $\mathrm{t}_{\text {tabel }}$ untuk $=0,05$ yaitu, $-0,230<$ 2.042, namun dilihat dari tingkat signifikannya (sig) lebih besar dari alpha (a) yaitu, 0,819>0,05 yang berarti tidak signifikan. Maka berdasarkan data ini dapat disimpulkan bahwa penguasaan konsep awal siswa tidak mempunyai perbedaan yang signifikan antara kelas kontrol dan kelas ekperimen.

Untuk mengetahui penguasaan konsep akhir siswa antara postest kelas kontrol dengan postest kelas ekperimen dapat dilakukan dengan membandingkan hasil pengujian ststistik. Dari hasil pengujian diperoleh nilai thitung sebesar $-4,268$ lebih kecil dari $t_{\text {tabel }} 2.042$ dengan tingkat probabalitas signifikan 0,000 lebih kecil dari nilai alpha 0,05 , artinya terdapat perbedaan yang signifikan antara skor penguasaan konsep akhir siswa kelas kontrol dengan kelas ekperimen. Perbedaan ini dapat dilihat dengan peningkatan gain pada kelas ekperimen lebih besar dibanding dengan gain pada kelas kontrol yaitu, 12,63 untuk kelas ekperimen dan 2,19 untuk kelas 
kontrol serta perolehan $\mathrm{N}$-gain 0,31 untuk kelas ekperimen dan 0,06 untuk kelas kontrol. (rekap pretes,postes gain -N-gain lihat lampiran IV)

Maka berdasarkan uraian diatas dapat dipahami bahwa penerapan model pembelajaran kooperatif tipe STAD dapat memberikan kontribusi yang signifikan dalam upaya meningkatkan penguasaan konsep siswa dibandingkan dengan penerapan pembelajaran dengan pembelajaran konvensional (biasa). Peningkatan penguasaan konsep siswa terhadap materi ajar yang terjadi pada kelas ekperimen meupakan bentuk kontribusi dari model pembalajaran kooperatif tipe STAD.

\section{Pembahasan}

Dari hasil perbandingan antara kelas ekperimen dengan kelas control itu, maka pembelajaran dengan menggunakan model pembelajaran kooperatif tipe STAD perlu diterapkan dalam pembelajaran IPS Madrasah Ibtidaiayah ataupun di Sekolah Dasar. Perlunya model ini diterapkan adalah karena model ini betul-betul secara empirik memberikan pengaruh terhadap penguasaan konsep siswa terhadap materi ajar. Hal ini di sampaikan oleh Ibrahim et, al (2007) bahwa pembelajaran dengan menggunakan model kooperatif bisa meningkatkan hasil belajar akademik, karena pembelajaran Cooperative Learning tipe STAD dapat memberikan keuntungan baik bagi para siswa kelompok bawah maupun kelompok atas yang bekerja bersama menyelesaikan tugas akademik. Siswa kelompok atas akan menjadi tutor bagi kelompok bawah, jadi siswa kelompok bawah memperoleh bantuan khusus dari teman sebaya yang berkemampuan baik (pintar). Dalam proses tutorial ini, siswa kelompok atas akan meningkatkan kemampuan akdemiknya, karena memberikan pelayanan sebagai tutor membutuhkan pemikiran yang lebih mendalam tentang materi itu sendiri.

\section{SIMPULAN}

Penguasaan Konsep Siswa Terhadap Materi Pembelajaran IPS. Pada awal sebelum dilakukan perlakuan terhadap kelas ekperimen, hasil tes penguasaan konsep siswa anatara kelas control dengan kelas ekperimen tidak jau berbeda, namun setelah dilakukan perlakuan terhadap kelas ekperimen dengan penerapan model pembelajaran kooperatif STAD sedangkan kelas dengan pembelajaran konvensional (biasa) menjadikan penguasaan konsep siswa kelas ekperimen terhadap materi ajar IPS menjadi meningkat sangat signifikan dibanding dengan kelas kontrol.

\section{DAFTAR RUJUKAN}

Abdul wahab. 2007. Metode dan ModelModel Mengajar Ilmu Pengetahuan Sosial (IPS). Bandung: Alfabeta.

Akdon. 2005. Aplikasi Statistika dan Metode Penelitian untuk Administrasi \& Manajemen. Bandung: Dewa Ruchi.

Al-Muchtar, Suwarma. 2004. Pengembangan Berpikir dan Nilai Dalam Pendidikan IPS. 
M. Taufik: Kontribusi Model Pembelajaran...

Bandung: Gelar Pustaka

Andayani, S. 2007. Penerapan Teknik

STAD dalam Pembelajaran

Matematika.

Badrudin.A. 2009. Konsep

Pendidikan IPS dan

Karakteristik Pendidikan IPS di $S D$.

Balen, S. Et al. 1993. Materi Pokok

Pendidikan IPS I. Jakarta:

Universitas Terbuka.

Dahar, R.W. 1989. Teori-teori Belajar.

Jakarta: Penerbit Erlangga.

Departemen Pendidikan dan

Kebudayaan. 1994. Kurikulum

Pendidikan Dasar 1994. Jakarta:

Depdikbud.

Ibrahim, M. Et al. 2007. Pembelajaran

Kooperataive.

Surabaya:

Universitas Negri Surabaya

Press.

Meltzer, David E. 2002. The

Relationship between

Mathematics Preparation and

Conceptual Learning Gain in

Physics: 'hidden variable' in

Diagnostic Pretest Scores'.

American Journal ojPhysics, 70,

(12), 1259-1267

Nana Sudjana. 2002. Penilaian Hasil

Proses Belajar Mengajar.

Bandung: Remaja Rosdakarya.

Nurhanurawati. 2004. Penerapan

Kooperatif Model STAD Dalam

Pemlejaran Limit Barisan Pada

Mahasiswa

Pendidikan

Matematika

Universitas

Lampung.

Sanjaya, Wina. 2007. Strategi

Pembelajaran; Berorientasi
Standar Proses Pendidikan.

Jakarta: Kencana.

Sapriya, Susilawati, Nurdin. 2006.

Konsep Dasar IPS. Bandung: UPI Press.

Slavin, R. E. 2008. Cooperative Learning: Teori, Riset, dan Praktik (terjemahan). Nusa Media. Bandung.

Sudrajat. A. 2008. Pendekatan, Strategi, Metode, Teknik, Taktik dan Model Pembelajaran.

Undang-undang No 20 tahun 2003 Tentang Sistem Pendidikan Nasional. 2003. Jakarta: Sinar Grafika. 